\title{
DÜBLIN
}

Technological University Dublin ARROW@TU Dublin

1999-01-01

\section{Street Children: a Comparative Perspective}

\author{
Kevin Lalor \\ Technological University Dublin, kevin.lalor@tudublin.ie
}

Follow this and additional works at: https://arrow.tudublin.ie/aaschsslarts

Part of the Psychology Commons

\section{Recommended Citation}

Lalor, K. (1999) Street children: a comparative perspective, Child abuse and neglect, Vol 23 (8), 1999, pp.759-770. doi:10.1016/S0145-2134(99)00047-2

This Article is brought to you for free and open access by the Social Sciences at ARROW@TU Dublin. It has been accepted for inclusion in Articles by an authorized administrator of ARROW@TU Dublin. For more information, please contact arrow.admin@tudublin.ie, aisling.coyne@tudublin.ie,gerard.connolly@tudublin.ie.






\section{STREET CHILDREN: A COMPARATIVE PERSPECTIVE}

\section{INTRODUCTION}

Street children have been a focus of attention for aid agencies and governments for little more than fifteen years. The issue first appeared as a major concern in the wake of the International Year of the Child (1979). In 1982 the Inter NGO Programme on Street Children and Street Youth was formed. In 1986 Unicef's Executive Board approved priority measures on behalf of "children in especially difficult circumstances." Special emphasis was placed on street children and for "developing strategies ... which would defend their rights, avoid their exploitation, and respond to their personal, family, and community needs" (Taçon, 1991, p. 1). The UN Convention on the Rights of the Child (Unicef, 1995) contains a number of articles which require signatories to improve the health, education and housing of all children. Such articles are particularly pertinent to street children.

Most academic work on street children originates in Latin America. For example, Felsman, 1981; Aptekar, 1988; Valverde and Lusk, 1989; Lusk, Peralta \& Vest, 1989; Connolly, 1990; Glauser, 1990; Lucchini, 1993a, 1993b, 1994a, 1994b; and Green, 1997. Work on a more global level includes Agnelli, 1986, Boyden, 1991 and Ennew, 1994. In contrast to Latin America, relatively little is known about the street children of Africa.

The purpose of this paper is to describe the results of recent research work in Ethiopia. Specifically, research findings on the age, gender, background, victimisation and delinquency of Ethiopian street children is compared to the existing Latin American literature.

\section{What are Street Children?}

That street children are a heterogeneous population was noted very early in the literature. For example, Unicef (1984) describes three main categories: children at risk, children of the street and children on the street. The largest group in this typology is the "children at risk" category. These are the children of the urban poor and they form the reservoir from which street children emerge.

"Children on the street" come to the streets to work in order to supplement their families' income, and they will return home to their families at night-time. A significant number attend school on a part time 
basis. Worldwide, these children perform similar tasks - they shine shoes, wash and mind cars, sell lottery tickets, magazines and newspapers, carry goods and peddle cigarettes and chewing gum. Extreme poverty has forced them to become at least partially self-supporting.

For "children of the streets", the street is their main living place. Family ties may exist but are remote and their former home is visited infrequently. A sub-category of street child in the Unicef typology is that of "abandoned children". This category includes orphans, runaways, refugees and others who have no contact with significant carers. In terms of lifestyle and daily activities, abandoned children are very similar to children of the street. They are distinguishable in that all ties with family have been severed, either through death, displacement or abandonment. Children of the street, on the other hand, have occasional contacts with their families. Of all street children, the category of the street and abandoned is the smallest. Only an estimated $5 \%$ to $10 \%$ of street children belong to this group of children of the street (Taçon, 1992). These children are more likely to make their livelihood by illegal means:

\footnotetext{
"They become premature adults and develop behaviour patterns which can be summarised in a rejection of authority, aggressiveness, an absence of limits, independence and a lack of affection. They are also ... characterised by problems with drug addiction, alcoholism, delinquency, prostitution and moral and physical abuse" (Unicef, 1984).
}

\section{METHODOLOGY}

In 1992, a Unicef funded survey of street children was carried out by the Ethiopian Ministry of Labour and Social Affairs (Molsa) in conjunction with University College Cork (Unicef, 1993). One thousand street children were interviewed; 400 in Addis Ababa and 200 in three other urban centres throughout Ethiopia. This survey collected data on street children's familial, socio-economic, migrational and educational backgrounds. It also explored the day-to-day details of the children's lives in terms of work, play, eating and sleeping habits. It further explored the interpersonal relationships of the children, their experience of abuse, both at home and on the streets, their involvement in crime and substance abuse and, finally, their health status. The following year, the author continued data collection in Addis Ababa. The objective of this further research was to gather data on the nature and 
incidence of victimisation and delinquency amongst both male and female street children. Collecting information from street children is not easy. Structured sampling techniques, or other forms of methodological sophistication are difficult to organise given the chaotic lives of the children and the turbulent world in which they live. A rapport and sense of trust between the children and the researcher is more important than developing what may in reality be spuriously sophisticated sampling procedures. The nature of work of this kind makes data collection an essentially emergent process, yielding reliable qualitative information from extensive interview and case study material. Interviewee location was facilitated by means of a street boy or girl well known in a particular area. Interviews and discussion groups took place in a variety of safe areas, particularly the compound of the Save the Children (USA) Drop-in Centre for street children. In total, 160 street girls and boys were interviewed regarding their experiences of victimisation on the street. An account of the specific methodologies is reported in Lalor (1998).

\section{ETHIOPIAN AND LATIN AMERICAN RESEARCH: A COMPARISON}

The following material consists of data from recent Ethiopian studies, which is contrasted with the profile of street children, as reported in the international literature.

\section{Gender}

Worldwide, there is a higher incidence of street boys than street girls. Espinola, Glauser, Oritz $\&$ Oritz de Carrizosa (1987) reported that $90 \%$ of the young street workers engaged in vending or service occupations in Asuncián were boys. In Columbia, the street child population is $75 \%$ male and 25\% female (Felsman, 1981; Aptekar, 1988). Felsman's (1981) sample of 120 Colombian gamins and Aptekar's (1988) sample of Colombian street children were comprised solely of males. Both cite the perception that girls who appear in the streets in Columbia are defined by the general population as prostitutes, not street children.

In Ethiopia, street boys and girls constitute, respectively, an estimated 75\% and 25\% proportion of the street child population (Unicef, 1993). However, the true incidence of working girls may be hidden by the nature of their work, which tends to be less visible than the work of street boys. 
For example, females may work as maids in bars, back street hotels and private houses. Street boys, on the other hand, typically engage in more visible activities such as car washing, shoe shining and peddling.

The worldwide trend of relatively fewer street girls than street boys might be explained by the position the female child holds in rural peasant life. In Nepal, for instance, the UN Food and Agriculture Organisation (FAO) analysed the contribution of women and children to both household and agricultural activities. Females were found to work more than males in all age groups and it was the family's dependence on girls' labour at home and in the fields which was responsible for females' lower rates of school enrolment (Acharya, 1982). It is reasonable to speculate that girls are prevented from working on the streets for similar reasons. In urban areas too, girls are more valuable to households due to their functions of looking after children and helping with chores, thereby freeing the mother to work outside the home. Connolly (1990) reports that in Latin America "girls are more needed within the family, as they are expected to perform household chores and care for younger siblings" (p. 139).

A further explanation for the lesser numbers of street girls when compared to street boys may be parental fears regarding the dangers of street life to females. In a study of 23 families of Ethiopian street children, Veale (1993) reported that parents were concerned and worried about the dangers associated with working on the street. She found that $70 \%$ of parents were not happy with having their children working. Similar findings were reported by Chatterjee from Indian parents: "studies show that employment for girls outside the home often ceases around the time of puberty to conform with socioreligious practice: parents are extremely reluctant to expose their daughters to male attention” (Chatterjee, 1992, p. 14).

Age

The majority of street children worldwide are aged between ten and fourteen years. Before age ten, parents appear to be loath to allow the child to enter the harsh world of the street (Veale, 1993; Chatterjee, 1992). Also, children younger than ten are not as capable of competing for the kind of work street children do. Once engaged in street life, the child's street "career" is often terminated by his or 
her changing appearance, as he/she grows older. By about fourteen or fifteen years of age, adolescents are beginning to lose their appeal to passers-by. This is particularly true for those who survive by begging:

"Before that time [adolescence], the children were considered cute, which contributed to their success at begging for alms. But as they grew, the image changed; they were then perceived as thugs and treated accordingly. When the street children reached puberty, they became street people" (Aptekar, 1989a, p. 793).

Thus, the age profile of street children appears to be a function of the nature of the demands of street life. In Ethiopia, it is estimated that approximately half of all street children are less than twelve years of age. The average age of initiation to street life is approximately eleven years (Unicef, 1993). As in many developing countries, children under sixteen years constitute $50 \%$ of the entire population (Aboud, Samuel, Hadera \& Addus 1991).

\section{$\underline{\text { Reasons for going to the streets }}$}

Children come to the streets for a variety of reasons: to find work, to escape family disharmony and as a result of becoming displaced or orphaned. For example, a study of Colombian street children found $36 \%$ of the children had left home due to extreme poverty, $27 \%$ due to family disintegration, $20 \%$ due to physical abuse and $10 \%$ due to a search for adventure (Pineda, de Munoz, Echeverry \& Arias, 1978). Aptekar (1988) recorded that $48 \%$ of his sample of street children in Cali, Columbia, were on the street for "financial reasons", but a further $32 \%$ were there because of abuse in the home. Thus, we can see that poverty alone is not the only reason for going to the streets. Abuse in the home is also reported as a significant factor.

In Ethiopia, reasons for coming to the streets are shown in Table 1:

Table 1. Reasons Given for coming to the Streets by 929 Ethiopian Street Children (extrapolated from Unicef, 1993, p.40)

\begin{tabular}{llc}
\hline $\begin{array}{l}\text { Reason for Coming to } \\
\text { the Streets }\end{array}$ & $\begin{array}{l}\text { Percentage of Children on } \\
\text { the Streets }(n=673)\end{array}$ & $\begin{array}{c}\text { Percentage of Children of } \\
\text { the Street }(n=256)\end{array}$ \\
\hline
\end{tabular}




\begin{tabular}{lrr}
\hline Economic Reasons & 72.6 & 30.5 \\
Family Reasons & 3.7 & 28.1 \\
Displaced/Orphaned & 2.1 & 30.1 \\
Join Friends/Play & 8.3 & 4.3 \\
Pressurised by Parents & 9.5 & 3.5 \\
Medical/Educational & 1.2 & 2.3 \\
Other & 2.7 & 1.2 \\
\hline
\end{tabular}

Nearly $60 \%$ of children living independently on the street are out of home because of family disharmony or due to being orphaned or displaced. This reason was given by only $5.8 \%$ of children who work on the streets, but who return home at night. This clearly indicates to us an important difference between these two different types of street children. In however limited or restricted a format, children on the streets choose to come to the streets in order to make money. Children of the street are more likely to come to the streets because there is nowhere else for them to go.

The reason children come to the streets is quite a complex one and is resistant to simple generalisations. For example, the reasons given by Eshete, an Ethiopian street girl, defy simple categorisation:

At age two Eshete's mother gave her into the care of relatives because she was destitute (gudifecha, an Ethiopian custom whereby children are accepted by those willing to raise them if parents are unable to do so). At age nine Eshete's adopting father died and she went to live with his brother for two years. At age eleven she went to Addis Ababa to search for her natural parents, whom she found were separated. She decided to live with her natural father, but he was a drunkard who always beat her. She ran away and went to stay with her natural mother, but she had two illegitimate children and could not afford to look after Eshete. So she left and found work in a rural hotel as a maid but the work was so hard that she soon left. A rural family adopted her and she minded their cattle for seven months. Eventually she came back to Addis Ababa at age sixteen and began living by begging. For a short time she lived as the "wife" of a taxi-boy but he eventually left her and she returned to living on the streets with friends (Lalor, 1997, p. 425). 
Eshete has lived an unusually irregular life but her story illustrates just how broken and unsettled the background of some street children might be. Interviews with a sub-sample of 69 street girls revealed that abuse at home was an important variable in choosing to come to the streets (Lalor, 1997). Twenty-five girls identified abuse as a reason for leaving home. The perpetrators of this abuse were reported as mother (11 cases), stepmother (10 cases) and stepfather, aunt, father and uncle (1 case each). These instances of abuse did not necessarily involve beatings: they included quarrelling, nagging, over-work, under-feeding and physical beatings. It is interesting to note that only one father and one stepfather are reported as having beaten their daughter/stepdaughter. With the exception of an uncle who simply refused to care for one girl, the remainder of girls who reported being abused at home experienced this abuse at the hands of women: mothers and stepmothers principally.

\section{Family Relations and Structure}

In general, street children report that they have good relationships with their families. Lusk (1989) reported that $90 \%$ of his Colombian sample had occasional or regular contact with their family. Felsman (1981) found that only $2.5 \%$ of his sample of Colombian street children had been abandoned: $61 \%$ maintained regular contact with their families. Boyden (1986) estimated that of the 200,000 children who work regularly on the streets of Lima, Peru, only 6,000 (3\%) actually live on the streets. Aptekar (1989b) reported that only $16 \%$ of his sample had no known family to contact. The remainder were in the care of at least one parent or a grandparent.

This being said, street children do tend to come from atypical families. In San Jose, Costa Rica, $78 \%$ of a sample of street children came from families with a single parent or no parent (Valverde and Lusk, 1989). Lusk and colleagues (1989) reported that only 44\% of their sample live with two parent families, $20 \%$ live with their mother and the remaining $36 \%$ live with relatives, or with other children on the streets. Brown (1987) reported that only $7 \%$ of street children in Kingston, Jamaica have two parent families.

The Unicef (1993) survey of 1,000 Ethiopian street children provided a wealth of data regarding the children's family backgrounds. The parents of Ethiopian street children are generally poor, whether rural or urban. Their educational status is typically low. One third of fathers and twice 
as many mothers were reported to be illiterate. Only $23 \%$ of the sample live with both parents. The bulk of the remaining children come from families where a spouse has been widowed (32\%), divorced (12\%) or "separated due to circumstances" (typically war) (7\%). Nine per cent of the sample are orphans. In spite of these varied family backgrounds, most street children have not broken contact with home. Over $80 \%$ of a sample of 1,000 see their family every day, suggesting that most Ethiopian street children are still integrally linked with their families (Unicef, 1993).

A similar profile emerges from Lalor's (1997) survey of 69 girls of the street in Addis Ababa. Only $16 \%$ of the sample arrived on the streets from a two-parent household. The largest number (30\%) came from a female-headed household. The remainder had either been orphaned or had previously lived in a wide variety of domestic situations, such as living with stepparents, mothers, aunts, uncles, grandparents, neighbours and adopting families. Excepting dramatic events such as being orphaned, children would appear to be protected from the streets, at least initially, by alternative domestic arrangements. However, it would appear that these alternative "safety net" arrangements appear to be susceptible to a breakdown that does leave the child on the street. This is evidenced by the number of girls of the street who report coming from a two-parent family (16\%) versus those who come from some alternative domestic situation, including working as a maid (84\%). We might speculate that nonparents might be less inclined to suffer hardship in order to support an adopted girl. Or, they may feel inclined to over-work the girl so that she might "earn her keep." We have already seen that a large number of the sample left for the streets because they felt they were being mis-treated, over-worked and under-fed by stepparents and other relatives.

\section{Victimisation of Street Children}

In the literature, the issue of victimisation of street children is assumed rather than specified. Most publications concerning street children refer to instances of street children being murdered in parts of Latin America by death squads allegedly organised by the police. Sadruddin Aga Khan and

Hassan bin Talal, Co-Chairmen of the Independent Commission on International Humanitarian Issues, reported that "in one large South American city, officially-licensed radio stations have urged private individuals to do away with street children physically. The result reportedly is not only widespread 
violence but the actual killing of two youngsters, on average, every day" (in Agnelli, 1986, p. 18). By 1993, this figure had risen to an estimated four children being killed a day. "Because they [street children] are increasingly blamed for the rising crime rate in Brazil's cities, they have now become prey: an average of four a day are killed" (TIME, 1993). In one particularly horrific incident during July 1993, five men opened fire on a group of fifty sleeping children in Rio de Janeiro. Three children died immediately and a further five died later from injuries. Three military policemen were arrested for the shootings (TIME, 1993). Human Rights Watch/America estimated that 5,000 children were murdered in Brazil between 1988 and 1991 (Guardian, 1/2/1994).

Lalor (1997) examined in some detail the victimisation experienced by street children in Addis Ababa. Widespread abuse of street children was reported. Interviews with 28 street boys revealed that being beaten is a weekly occurrence for approximately one third of the sample. More than half reported being "regularly" physically attacked on the streets, frequently severely. Injuries from stabbing, slashes from razor blades, fractured skulls and broken bones were quite common even among this small sample. Such injuries are most often inflicted during fights with other street boys. Disputes typically arise over "rights" to work in a particular area or perceived insults.

Theft against street boys, particularly younger boys, is widespread. It is not an exaggeration to say that street boys are likely to be robbed of anything remotely valuable, usually by older street boys, unless they can find a safe place to keep it.

As shown in Table 2, the victimisation street girls experience centres primarily on sex and theft.

Table 2. Summary of the Nature and the Incident of Victimization Experienced by Girls of the street (n $=69)$

Theft Beatings Solicitation Rape Prostitution Sexual Attacks Pregnancy

\begin{tabular}{llllllll}
$\begin{array}{l}\% \text { of Street Girls } \\
\text { Experiencing }\end{array}$ & 81 & 78 & 75 & 44 & 44 & 26 & 25 \\
\hline
\end{tabular}

While it is rare for street girls younger than twelve to be raped, it does occur. The average age of first experience of rape is 13.8 years. The perpetrators of rape against street girls are usually street 
boys. The reason street boys give for raping girls is that they have no money to pay for prostitutes and also that they can be certain that a girl who is not a prostitute will not have any venereal diseases or Aids. To avoid such attacks, girls try to be indoors before dark. In effect, they impose a nightfall curfew upon themselves. Almost all sexually mature street girls will be routinely solicited for sex. The girls in this sample who were not solicited were either sexually immature, visibly pregnant or had a child. Over $40 \%$ of street girls resort to prostitution at some point.

Younger girls are a particularly victimised group. Those in their early teens are routinely threatened, intimidated and robbed by older boys. Those that refuse to part with their earnings are often beaten into acquiescence. Coming from communities where theft may be practically non-existent, rural children are often naive as to the harshness of the city and the bus-station is where many first lose their clothes and money to opportunistic older adolescents. Girls may innocently hand over their bag to someone who offers to carry it (often a member of their own tribe) and suddenly it is gone.

Girls on the street differ from girls of the street in that they sleep at home and, consequently, experience considerably less victimisation. The beatings they experience are typically mild and infrequent. Thefts typically consist of boys stealing small quantities of their wares. Only one girl from a sample of 35 reported having been raped, and attempts were made to sexually assault another five. Nevertheless, fear of rape was widely reported. The majority of this sample reported that they do not feel safe on the streets. None were involved in prostitution and none have ever been pregnant.

\section{Delinquency}

The delinquency of street children has been relatively well researched. A frequent observation has been the increasing involvement of street boys in theft, as they progress through adolescence (Felsman, 1981; Aptekar, 1988; Lusk, 1989). Whilst younger boys mainly practice petty theft such as stealing food from shops/markets, older boys may become involved in more confrontational crimes such as pick-pocketing and robberies. Inevitably, such activities bring street children into contact with the police, or other security forces. They are frequently viewed as a threat to society, as delinquents or criminals. Slang words used by the police for street children include "the plague" or "dirty faces" (Columbia), "vermin" (Ethiopia) and "mosquitoes" (Cameroon). 
Lusk (1989) outlined a three-stage typology of delinquency development in Columbia. A pregamin is a pre-adolescent child who lives at home but spends part of his time on the streets in order to supplement family income. While on the street, he is likely to engage in petty theft when the opportunity arises. A gamin is an adolescent with looser family ties and he spends more time on the street, even sleeping there. Typically, this type of youth lives with other gang members in a rented room or flat and may be self-supporting through illegal activity. Finally, the largos are the older adolescents who have fully taken on the street life and ethic. They are enmeshed in hardcore street life, and are likely to develop into adult criminals (Lusk, 1989, pp. 58-59).

Lusk's typology (1989) conforms to the pattern of delinquency development observed elsewhere. According to Aptekar (1988), this development of street boys from petty thief to hard-core criminal is almost inevitable:

"Our study indicated that they were almost no possibilities for the gamine facing puberty ...

The gamines, as they grew older, were compelled by their perceptions of themselves as haughty provocateurs to give up small scale mischief and become either full-scale delinquents or find a way to live outside the mainstream of the larger society" (pp. 76-77).

In Ethiopia, the "career" of street boys would also appear to be marked by a gradual intensification of delinquency. For example, Unicef (1993) found that twice as many boys in the 13-15 year age group self-reported stealing compared to boys in the 10-12 year age group. Also, boys are more likely to have been imprisoned and are more likely to chew khat (a mild narcotic plant), drink alcohol and smoke cigarettes at ages 16-18 than at ages 11-15. Broadly speaking, street boys can be divided into two categories. Specifically, the older child who steals money or resaleable items in order to support expensive habits such as drinking, chewing khat or smoking; and the younger child who steals either food or money to buy food. The latter category is a considerably larger group. However, there exists in Addis Ababa a small hard core of delinquent street boys who steal, rape, fight, beat up younger children, drink to excess and use prostitutes. However, in spite of deliberately targeting deriyeas (delinquents) in this study (Lalor, 1997), interviews with street boys revealed large numbers who do not fit the above description. It would appear that the stereotype of the wild, uncontrollable street boy is ill founded in Ethiopia. The street children of Addis Ababa have been described by the 
late Peter Taçon, International Consultant on Street and Working Children, as “innocent lambs compared with those in South America” (Taçon, personal communication). Such a low level of hard core criminality in Addis Ababa is perhaps due in part to the policing of the city. Soldiers of the Ethiopian Peoples' Revolutionary Democratic Front (EPRDF), which overthrew the Marxist-Leninist dictator, Mengistu, took on the role of policing in May 1991. The EPRDF soldiers continued to be solely responsible for policing the city until 1993. What can only be described as "blanket coverage" of the city by armed soldiers was in operation between 1991 and 1993. Interviewees reported anecdotal accounts of the shooting of looters, many of which were opportunistic street boys. Their bodies were reportedly left on the streets overnight as a warning to other would-be robbers. Further to the issue of policing, an apparent difference between Ethiopian and Latin American street children is the degree to which they are alienated by society. Aptekar (1988) described all his sample of Colombian street boys as having a "non-conformist attitude toward society" (p. 46). Whereas there are problems of delinquency and anti-social behaviour among the street children of Addis Ababa, it is not accurate to say that they possess "a non-conformist attitude towards society." Rather, traditional values of discipline, hard work and respect are, to a large degree, still intact. Ethiopian street children are considered to be better behaved and less violent than their South American counterparts. They are less involved in delinquency and are more likely to retain traditional values such as respect for the aged and a belief in religion (Taçon, personal communication). Unfortunately, all the indicators point to an increase of youth crime in Addis Ababa. The population of the city doubled between 1991 and 1993, work is increasingly scarce, family breakdown is widespread, poverty is rife and no serious or effective efforts have been made by the authorities to contain, or deal with the problem of youth crime.

\section{Drug Use}

A number of authors have investigated the incidence of drug use amongst street children. For example, Lucchini (1993b) estimated $80 \%$ of street children in Brazil consume drugs (p. 17). The drugs most widely used by Brazilian street children are inhalants - glue, aerosol, varnish and stain remover. However, levels of addiction appear to be low. Indeed, many children are able to stop consumption at once (Lucchini, 1993b). It is primarily younger children who consume inhalants. Cocaine use is rare and is practised only by the oldest adolescents. Connolly (1990), too, reported that 
"hard drugs are virtually unknown" amongst street children in Bogotá (p.144). Drug use among street children would appear to be a relatively controlled activity involving drugs such as inhalants, alcohol or hashish. Younger street adolescents rarely use hard drugs or experience the addiction associated with them. Dallape (1988) noted the controlled nature of drug taking amongst street children in Nairobi "overdoses are not tolerated and street children force each other to moderation" (p. 18, cited in Ennew, 1994, p. 23). Aptekar (1988), too, stated that drug use was not as prevalent among the street child population as commonly believed - "Drug use for the most part simply was not central to the street children's lives" (p. 142). Their lifestyle cannot afford the exclusive focusing of their energies on drug procurement and consumption:

\footnotetext{
"The ecology and the rhythm of survival in the street are elements that limit the effects of consumption on dependency. Other elements come to strengthen this protective effect. For instance, the inhalants are most of the time consumed in the street and collectively ... Withdrawal on oneself is incompatible with consumption of inhalants" (Lucchini, 1993b, p. 28).
}

Nevertheless, there are street children who do not restrict their indulgence in chemical substances - "the heavy users are easily recognised by their ragged clothing, soiled faces, and glazed eyes, and the effects of brain damage are observable among long-time users" (Connolly, 1990, p. 144).

An interesting profile of drug use emerges from the Ethiopian data. Comparable to what researchers have found in other countries, little evidence was found for the use of hard drugs amongst street children in Ethiopia. Also, there would appear to be little evidence of addiction.

Table3. Frequency of Drug Use as Reported by 1,000 Ethiopian Street Children (Extrapolated from Lalor, 1997)

\begin{tabular}{lccccc} 
& $\begin{array}{c}\text { Daily } \\
\%\end{array}$ & $\begin{array}{c}\text { Weekly } \\
\%\end{array}$ & $\begin{array}{c}\text { Rarely } \\
\%\end{array}$ & $\begin{array}{c}\text { Never } \\
\%\end{array}$ & $\begin{array}{c}\text { No Response } \\
\%\end{array}$ \\
\hline Alcohol & & & & & \\
Cigarettes & 1.6 & 2.4 & 11.9 & 83.6 & .5 \\
Khat & 3.2 & .1 & 1.6 & 94.5 & .6 \\
Benzene & .4 & .4 & 2.2 & 92.7 & .7 \\
Other & .2 & .1 & 1.8 & 97.5 & .4 \\
\hline
\end{tabular}


The majority of drug using street children in Addis Ababa, as we can see, report frequency levels of once a week or less (Lalor, 1997).

There a number of idiosyncrasies in the types of drugs used by Ethiopian street children that are worth mentioning. Firstly, khat chewing is both legal and widespread throughout Ethiopian society. Street children who chew khat once a week with friends could not be considered to be engaging in a marginalised, forbidden activity. Secondly, home-made alcohol is also widely consumed on holy days and other holidays. Thus, a large degree of the alcohol consumption reported by this sample consists of modest amounts consumed with parental approval.

\section{The Group}

Street children are vulnerable to abuse and victimisation from the police, from other street children and from customers and passers-by on the streets. Primarily to protect themselves from this victimisation, street children usually organise themselves into gangs. A further function of the group is to fulfil primary familial needs such as protection, sustenance and nurture (Lusk et al., 1989; Connolly, 1990). The gang

"provides the protection and comradeship of a substitute family, status, excitement, and a code of 'honour' - rules to which, unlike those of conventional society, the youngster can conform. It also meets the need, in particular, for a sense of identity, which is sometimes reinforced by esoteric slang” (Agnelli, 1986, p. 39).

Aptekar (1989a) attributed the adequate mental health of street children, in spite of their lifestyles, to the intense friendships they form within their groups. These intense "chumships" border on love and ameliorate the effects of past emotional trauma.

Ethiopian street children also form themselves into groups. All but two of a sample of 69 girls of the street were found to belong to a specific group (Lalor, 1997). The majority of street girls who appear to be working and living alone on the streets are in fact almost never alone. Most of a girl's activities (sleeping, working, eating, and recreation) are carried out within her group. Her friends are 
an important source of protection and companionship. Particularly in the event of becoming sick or of being attacked on the streets, the group plays an important protective/nurturing role without which many girls would find street life untenable. Girls typically beg in small groups of three or four. Similarly, juvenile prostitutes stand in small groups under lamp-posts while waiting for customers. In the event of one of their number being robbed, they will scream and attract the attention of passers-by or the police. The group is particularly important for those street children who have lost all contact with their families. Baardson (1993) reported that groups of juvenile prostitutes support each other both economically and emotionally. "For the vast majority of the girls in the survey, the network among the girls was the only security system they had" (Baardson, 1993, p. 34). For girls on the street, the group is also important. A girl may borrow money from her friends in a time of need or, in the event of becoming sick, ask her companions to sell her wares. In the event of being harassed on the streets by customers or passers-by, her friends will intervene in some way. However, the functions of the group are not nearly so vital and life supporting as they are for girls of the street. For girls who work on the street but sleep at home, the group offers protection from harassment, and a pool of people from whom one can borrow money, but these girls generally do not eat or sleep together.

\section{The Outcomes of Street Life}

The degree to which street children are emotionally and intellectually well adjusted was a primary finding of Aptekar's (1988) work. Felsman's (1981) work also highlighted the resilience and adaptability of street children and their apparent ability to thrive in difficult circumstances.

In the absence of longitudinal data, we can only speculate as to what the outcomes might be for children who have spent time on the streets. It is interesting to ponder the extent to which researchers may have biased their sample towards healthy, functional children by carrying out research with confident children who volunteer their services, are happy to communicate openly with a foreign researcher and, overall, are easier to deal with than suspicious, withdrawn or aggressive children. Of course, not all street children are well adjusted:

"There is no doubt that many simply perish ... In many cases, knife and gunshot wounds are the cause of death, while tragic street accidents claim others. Thus, while most gamines have 
the ability and are fortunate enough to survive, their lifestyle is inherently dangerous and the street claims many young victims" (Connolly, 1990, p. 145).

Lalor (1997) asked girls of the street and girls on the street what they perceived the results of having lived on the streets might be. For girls of the street, 114 responses were collected from a sample of 32 girls. Every single response contained a negative consequence of street life, most of the respondents mentioning lack of education, ill health and physical and sexual assaults. No positive aspects of life on the street were mentioned. This would seem to lay to rest the myth that street children are free spirits existing in a childhood idyll free of adult interference. It is true to say that street life is an unspeakably miserable experience for many girls of the street. For girls on the street, the responses were also primarily negative. Perhaps reflecting the additional security they enjoyed over girls of the street, this sample was less concerned with their physical well being (although this remained a primary concern, mentioned by $29 \%$ ). The single greatest concern was that their street work would interfere with their education and consequently their prospects in life. Again, no positive aspects of street life were mentioned.

\section{CONCLUSION}

We have seen that there are similarities between Latin American and Ethiopian street children in terms of age, gender, family background and reasons for coming to the streets. The more visible aspects of street children's lives have been investigated - where they come from, how they eat, the kinds of work they do and their peer groups. However, little is known about the developmental consequences of street life, what the child's work means to his or her family or about how adolescents decide to leave the streets. Almost nothing is known about how a street child's psychological and physical health compares to that of his sibling's or neighbours who do not work. Until now, no research has focused on the abuse and victimisation street children experience. There has now evolved a need for research that moves beyond the descriptive level. Cross cultural comparisons would serve to illustrate the highly idiosyncratic cultural and economic influences on the very existence of street children and a longitudinal study would help us to understand the consequences, both positive and negative, of street life. 


\section{BIBLIOGRAPHY}

Aboud, F., Samuel, M., Hadera, A. \& Addus, A. (1991). Intellectual, social and nutritional status of children in an Ethiopian orphanage. Social Science and Medicine, 33, (11), 1275-1280.

Acharya, M. (1982). Time use data and the living standards measurements study. Washington, D.C.: Development Research Department, World Bank, LSMS Working Papers, No. 18.

Agnelli, S. (1986). Street children: A growing urban tragedy. London, UK: Weidenfeld and Nicolson.

Aptekar, L. (1988). Street children of Cali. Durham, NC and London, UK: Duke University Press.

Aptekar, L. (1989a). Colombian street children: Gamines and chupagruesos. Adolescence, XXIV, 96, 783-794.

Aptekar, L. (1989b). Characteristics of the street children of Columbia. Child Abuse and Neglect, 13, 427-437.

Baardson, P. (1993). Child prostitution in Addis Ababa. Addis Ababa, Ethiopia: Unpublished Radda Barnen report.

Boyden, J. (1986). Children in development: Policy and programming for Especially Disadvantaged Children in Lima. Oxford, UK: Unicef.

Boyden, J. (1991). Children of the cities. London, UK: Zed Books Ltd.

Brown, C. (1987). Street children in Jamaica. Paper presented the conference on street children, University of the West Indies, Kingston, Jamaica, November, 1987. 
Chatterjee, A. (1992). India: The forgotten children of the cities. Florence, Italy: Unicef.

Connolly, M. (1990). Adrift in the city: A comparative study of street children in Bogotá, Columbia and Guatemala City. Child and Youth Services, 14, (1), 129-149.

Dallape, F. (1988). An experience with street children. Nairobi: Undugu Society.

Ennew, J. (1994). Street and working children: a guide to planning. London, UK: Save the Children, Development Manual 4.

Espinola, B., Glauser, B., Ortiz, R. \& Ortiz de Carrizosa, S. (1987). En la calle, menores trabajodores de la calle en Asuncián. Bogotá, Columbia: Unicef Methodological Series.

Felsman, J.K. (1981). Street urchins of Cali: On risk, resiliency and adaptation in childhood. Harvard University, MA: Unpublished Ph.D. thesis.

Glauser, B. (1990). Street children: Deconstructing a construct. In A. James \& A. Prout (Eds.), Constructing and reconstructing childhood: Contemporary issues in the sociological study of childhood (pp. 138-156). London, UK: The Falmer Press.

Green, D. (1997). Hidden Lives: Voices of Children in Latin America and the Caribbean. London, UK: Latin American Bureau.

Guardian Newspaper, London, UK. Brazil Child Killings, p.11, 1/2/1994.

Lalor, K. (1997). Victimisation of street children in Addis Ababa: Factors of resilience and susceptibility. Unpublished Ph.D. thesis: University College Cork: Ireland. 
Lalor, K. (1998). Researching the victimisation of street children in Addis Ababa: Methodological issues. In Conference Proceedings, Researching Children's Experiences: Qualitative Approaches (pp. 27-34). Trinity College Dublin, Ireland: The Children's Research Centre.

Lucchini, R. (1993a). Street children: A complex reality. University of Fribourg, Switzerland: Institute for Economic and Social Sciences, Working Paper No. 224.

Lucchini, R. (1993b). Street children and drug consumption in Brazil. Thoughts about addiction. University of Fribourg, Switzerland: Institute for Economics and Social Sciences, Working Paper No. 231.

Lucchini, R. (1994a). The street children of Montevideo and Rio de Janeiro: Elements for a differentiation. University of Fribourg, Switzerland: Institute for Economics and Social Science. Working Papers.

Lucchini, R. (1994b). The street girl: prostitution, family and drugs. University of Fribourg, Switzerland: Institute for Economics and Social Sciences, Working Paper No. 243.

Lusk, M. W. (1989). Street children programs in Latin America. Journal of Sociology and Social Welfare, 16, (1), 55-73.

Lusk, M. W., Peralta, F. \& Vest, G. W. (1989). Street children of Juarez: a field study. The British Journal of Social Work, 32, 289-302.

Pineda, V.G., de Munoz, E., Echeverry, Y. \& Arias, J. (1978). El gamin: Analisis de datos secundarios. (The street urchin: Secondary analysis). Bogotá, Columbia: Litografia Arco.

Taçon, P. (1991). Protection, respect, and opportunity for the street children of Ethiopia. Unpublished Consultant's report to Representative of Unicef in Addis Ababa, Ethiopia. 
Taçon, P. (1992). Marco and the malevolent monsters. Unpublished paper for presentation to the Organisation of African Unity and its international partners.

TIME International (1993). Rio’s dead-end. August 9, No. 32.

Unicef (1984). Latin American seminar on community alternatives for street children. Brasilia, Brazil. November 12-15, 1984.

Unicef (1993). Study on street children in four selected towns of Ethiopia. Addis Ababa, Ethiopia: Unicef.

Unicef (1995). The convention on the rights of the child. London, UK: UK Committee for Unicef.

Valverde, L. \& Lusk, M. (1989). Street children of San Jose, Costa Rica. Logan, Utah: Utah State University, Department of Sociology and Social Work, Research Monograph No. 2.

Veale, A. (1993). Community study. In Unicef (1993), Study on street children in four selected towns of Ethiopia (pp. 89-93). Addis Ababa, Ethiopia: Unicef. 